\title{
Muslim Minorities as Germany's Past Future: Islam Critics, Holocaust Memory, and Immigrant Integration
}

\author{
Esra Özyürek \\ London School of Economics \\ European Institute
}

\section{Abstract}

A new cohort of Turkish- and Arab-background public intellectuals in Germany locate the root of problems of migrant communities in a resemblance between Islamic culture and Nazi ideology. Islam critics promote the idea that if, like the children of Nazis before them, children of Muslims can rebel against their fathers and sexually liberate themselves, they will also be able to embrace the democratic values of German society. In their best-seller books Islam critics aim to include migrants in the German national temporal framework and also enable a new interpretation of German history not as an anomaly, an evolutionary modernization story gone terribly wrong, but as an historical model that other nationalities should also pass through and come out of. By studying how highly popular Islam critics position Muslims in relation to memory of National Socialism in Germany this article asks what kind of transformation (and reproduction) is German Holocaust memory and public political culture is undergoing in its perception of its relationship with its Nazi past on the one hand and its multi-ethnic present and future on the other. It also asks what role Muslims and other minorities play in shaping, reacting to, and corresponding with these transformations. By focusing on the unlikely promise of inclusion of the Muslim minority in the German national temporality through path dependent repetition, it argues that national memory 
Ozyurek, Esra (2019) Muslim minorities as Germany's past future: Islam critics, holocaust memory, and immigrant integration. Memory Studies. ISSN 1750-6980 (In Press)

cultures are formed in relation to and with the help of minorities who are being simultaneously incorporated and excluded from the present at once.

\section{Keywords}

\section{Holocaust memory, Muslim minority, Islam critic, immigrants, temporality, Germany}

\section{Acknowledgements}

Irit Dekel, Julian Göppfarth, Ruth Mandel, Yael Navaro, Damani Patridge, Burak Yılmaz, Gökçe Yurdakul, and audiences at Harvard University, University of Illinois, Urbana-Champaign, Northeastern University, Mount Holyoke College, Cambridge University, Chicago University, Edinburgh University, Northwestern University, and Cornell University helped me to think through issues in this article. I am grateful for their contributions.

\section{Introduction}

In the 1990s, when victim-centered Holocaust memory was becoming institutionalized in Germany, Turkish-background immigrants likened themselves to Jews in order to attract attention to their marginalization within German society (Mandel, 2008). Following the fire bombings of Turkish houses in Mölln in 1992 and in Solingen in 1993, Turkish German activists organized successful protests with the slogan, "We do not want to be the Jews of tomorrow" (Yurdakul and Bodemann, 2006). Similarly, in fiction written by Turkishbackground authors in the 1990s "Turkish figures align themselves with, stand in for, and reenact Jewish figures" (Konuk, 2007, 236). In startling contrast, in the 2000s Turkish- 
Ozyurek, Esra (2019) Muslim minorities as Germany's past future: Islam critics, holocaust memory, and immigrant integration. Memory Studies. ISSN 1750-6980 (In Press)

Iranian- and Arab-background public intellectuals refrain from likening themselves to Jews. Some of them relate to the German memory culture through the memories of violence they brought to the country, such as the Armenian Genocide (Konuk 2007, Rothberg and Y1ldiz 2010, Von Bieberstein 2017). A more visible and publicly recognized group on the other hand establishes timeless similarities and direct connections between Islam/Muslims and National Socialism.

Within this new cohort of self-declared Islam critics one group appeals mostly to the right end of the political spectrum. In his international best-seller Islamic Fascism (2014) Egyptian born Hamed Abdel-Samed argues that core principles of Islam such as belief in one god and ultimate truth are fascistic and that the ideology and program of Muslim Brotherhood, the original Islamist movement established in 1920s, had direct ties to Nazis. When Abdel-Samed says, "Islamism is the fascism of $21^{\text {st }}$ of century" (Finger 2015), Mina Ahadi, the Iranian born chairwoman of ex-Muslims in Germany, takes this argument one step further and states that Islam as a whole is comparable to fascism (Crolly 2007). The most prominent Turkish background Islam critic, Necla Kelek, recommends that Muslims should be treated like fascists, meaning not tolerated in Germany (Klaieber 2018). Such radical statements resonate with similar statements being made by other ex-Muslims in other countries, such as Ayaan Hirsi Ali of the Netherlands or Zineb El Rhazoui of France.

A second and smaller group within the same cohort that identifies itself with the left, and more specifically with the Green Party, although also appeals to the conservative circles as well. The most visible representative of this group is Ahmad Mansour, an Israeli Arab background recent immigrant to Germany, who likens Muslims to early post-War Germans who have the potential of being reeducated and embracing German/European democratic 

immigrant integration. Memory Studies. ISSN 1750-6980 (In Press)

values, if they follow the footsteps of the children of the defeated Germans. Recipient of dozens of prestigious awards, a constant presence in mainstream media, and leader of several social work projects Mansour applies authoritarian personality theories developed during and after WWII to understand and transform fascistic tendencies in the German culture to do the same with Muslims today (2014). Turkish and Kurdish background lawyer and activist Seyran Ateş similarly argues that the root of the problem among Muslim communities today is the one Nazis had: sexual oppression (2011). She suggests if today's Muslims follow the footsteps of the German youth movement of 1968 by rebelling against their fathers and sexually liberating themselves, they too will be able to embrace democracy, combat antiSemitism and sexism, and be enabled as autonomous individuals. Such Muslim background Islam critics themselves walk on the footsteps of post-War German intellectuals such as Jurgen Habermas, Martin Walser, Ralf Dahrendorf, Gunther Grass, and Hans Magnus Einzsberger who saw their primary responsibility to promote the democratic culture established in 1949. Like German "engaged democrats" (Forner, 2014), Islam critics distrust and distance themselves from their people and aim to shepherd them towards selftransformation (Muller, 2000: 8).

This article attempts to understand why and how come a new cohort of Muslim background intellectuals and activists at different ends of political spectrum liken the contemporary Muslim minority Germans during the Third Reich or after the defeat in the World War II, both before their arrival en masse to Germany? Considering the widespread recognition and legitimacy these Islam critics have in Germany, I ask what kind of transformation (and reproduction) is German Holocaust memory and public political culture is undergoing in its perception of its relationship with its Nazi past on the one hand and its 
multi-ethnic present and future on the other. Furthermore, what role Muslims and other minorities play in shaping, reacting to, and corresponding with these transformations? By focusing especially on the ordering of different temporalities to coeval events, in this case Germany's confrontation with its Nazi past and the post-war migration, I argue that national memory cultures are formed in relation to and with the help of minorities who are being simultaneously incorporated and excluded at once (Partridge, 2008).

\section{Locating Muslim immigrants in the sediments of German time}

Anthropological and Orientalist discourses have long positioned contemporaneous cohabiting groups on an imagined linear timeline that serves to set them apart both spatially and temporally. Johannes Fabian argues that, rooted in the Judeo-Christian tradition's salvationist ideology, the linear conception of time is on the one hand incorporative: "they create a universal frame of reference able to accommodate all societies" (Fabian, 2014: 26). On the other hand, linear time's epistemological basis in historicism serves to distance and separate coeval societies: "What makes the savage significant to the evolutionist's Time is that he lives in another Time" (Fabian, 2014: 27). Together these two effects turn historical time into "the measure of cultural distance... that was assumed to exist between the West and the non-West" (Chakrabarty, 2000: 7). Europeans of colonial or postcolonial background are also often framed as lagging behind evolutionary time. According to Fatima El-Tayeb, this is why even third-generation Europeans of color are still called migrants: they are permanently "not here, not yet" (El-Tayeb, 2016). It is for this reason thinking about Muslim background immigrants' relationship to German democratization and coming to terms with the crimes of the Third Reich has been a challenging project, as it involves bringing together anxieties 

immigrant integration. Memory Studies. ISSN 1750-6980 (In Press)

about the past, present, and future together - something Günther Grass called Vergegenkunft, a term which mixes the German nouns for the three tenses (Grass, 1980: 127).

In recent years the Holocaust has come to be considered a monumental event not just by Germans and European Jews, but also by Europeans (Assmann, 2014), Americans (Flanzbaum, 1999), and others around the world (Huyssen 2003). But in discussions around Holocaust memory European Muslims have appeared almost exclusively as challenges. In the early 2000s, German and other west European newspapers began to run stories about how Muslim students were refusing to attend concentration camp tours and would not engage with material in history classes devoted to the discussion of National Socialism (Kouparanis, 2008; Ulrich et al., 2010). German popular discourse located Muslims lower down in the evolutionary ranking of groups according to their ability to learn the lessons of the Holocaust and hence participate in the German democratic post-war culture. The effect of this narrative was both to erase the seventy-year long history of Muslim background Germans who have contributed to different dimensions of postwar German reconstruction and to depict Germans as having reached their destination by dint of having come to terms with the Holocaust (Wilds, 2013).

Another way of looking at postwar Germany in its fuller complexity would be to recognize that temporality is not arranged along a straight line where disparate groups march one after the other toward confrontation with and acknowledgment of Holocaust and a resulting democratization. Postcolonial scholars suggest that there is no one universalizing homogenous time, but rather that "a plurality of times exist together" (Chakrabarty, 2000: 109) where presents, pasts, and futures interlock, "each age bearing, altering, and maintaining the previous ones" (Mbembe, 2001: 16). The German historian and philosopher Reinhardt 
Koselleck, who came of age in postwar Germany, has a clear analytical model of such temporal coexistence and what he calls the "simultaneity of the nonsimultaneous" (die Gleichzeitigkeit des Ungleichzeitigen) and "sediments of time (Zeitschichten)" (Koselleck, 2000; Koselleck, 2018: 3). The powerful image he uses in this model is that of layers of history imposed one upon the other, where some layers are older, deeper, and solidified and some are more volatile: "Historical times consist of multiple layers that refer to each other in a reciprocal way, though without being wholly dependent upon each other" (Koselleck, 2018: 4). Koselleck argues that in the experience of these sediments of time in their multiplicity, past, present, and future are always understood in terms of each other; more precisely, both the past and the future are experienced in the present, where the present is constantly fleeting (Koselleck, 2018: 102-103). Jeffrey Olick suggests such complex relationships between multiple levels of historicity can be explained in terms of "path dependency" (1999: 382), where "images of the past depend not only on the relationship between past and present but also on the accumulation of previous such relationships and their ongoing constitution and reconstitution" (1999: 382). How do a new cohort of Muslim background Islam critics relate the German past, present, and future, or to its Vergegenkuft in Grass' terminology, in order to include the Muslim minority into the complex matrix of German national temporal frame? And at what cost?

\section{Past futures, or working through the past}

Over the past two decades, scholarship on Holocaust memory has focused on the changing nature of memory culture in Germany. The current victim-centered memory culture that is officially promoted conceives the Holocaust as an unquestionable "negative myth of origin" and "a primal phantasmatic scene of guilt and shame around which German national 
identifications are organized" (Moses, 2001: 94). But in fact, this conception became mainstream only after Germany unification in 1990. Prior to this, Eastern and Western Germans had different approaches to dealing with the Nazi past. In the west, the Federal Republic of Germany was keener on coming to terms with the crimes of National Socialism (Niven, 2002). In 1978, West German Chancellor Helmut Schmidt (1974-82) became the first German leader to visit a synagogue and ask for reconciliation with Jews, emphasizing, however, the innocence of today's Germans (Wolfgram, 2011: 66). In the east, the former German Democratic Republic declared itself the successor to the WWII resistance movement and thus refrained from encouraging its citizens down the thorny path of soul-searching (Fox, 2001). Despite these differences, until the 1980s, East and West Germany promoted similar myths that made ordinary Germans seem like innocent victims: both versions of Holocaust memory culture held that Germans and Nazis were two separate groups and that the Nazi state had terrorized everyone in Germany. As late as 1986, conservative historians from West Germany argued that it was time to view Germany's past as not distinctly evil and to consider the crimes of Nazism as akin in severity to those of Bolshevism (Kampe, 1987). As the chancellor who oversaw German unification, the conservative Helmut Kohl (1982-1998) was interested in focusing on the positive aspects of German history, those prior to World War II. After the unification, Jürgen Habermas played a crucial role in the official embrace of a victim-centered commemoration where Germans take full responsibility for the Holocaust as a proof of their responsible citizenship (Karyn, 2009). Chancellor Gerhard Schröder (19982005) led a new turn in the memory culture that transformed the act of coming to terms with the past into a positive attribute of German society. He insisted that Germany could be more positive about its past precisely because it had faced it (Welch and Wittlinger, 2011). In a 
Ozyurek, Esra (2019) Muslim minorities as Germany's past future: Islam critics, holocaust memory, and immigrant integration. Memory Studies. ISSN 1750-6980 (In Press)

1999 interview, Schröder declared that the new generation's willingness to face their past is a source of empowerment that creates "an opportunity to represent one's own interests in a more uninhibited manner" (Welch and Wittlinger, 2011: 47). Coming just at the turn of the twenty-first century, Germany's ability to confront its dark past came increasingly to be seen as the mark of a special kind of moral aptitude which served to legitimize Germany's reappearance on the world stage (Markovits, 2006).

The crystallization of German Holocaust memory as victim-centered and the accompanying sense of "moral superiority" (Frochtner, 2014) for having found the correct method of coming to terms with the past coincided historically as well as ideologically with the entry of Turkish and Arab immigrants into the national discussion of Holocaust memory. The contemporary sense of responsibility hence is directed not only towards the past crimes but also simultaneously towards evaluating and educating immigrants (author 2018). While Turkish-background Germans in particular have long engaged with the memory of the Holocaust, these engagements have by and large been ignored by the general public (Konuk, 2007). When in the early 2000s German and west European newspapers began to run stories about the refusal of Muslim students to attend concentration camp tours and engage with class material devoted to the history of National Socialism (Ozyurek, 2018), a twin public discourse began to dominate concerning the Muslim importation of anti-Semitism into a country that had already come to terms with its own anti-Semitism (Ozyurek, 2016). In response, some Muslim-background public intellectuals popular in mainstream society for their critical position toward Muslims and Islam promoted the idea that Muslims are exactly at the point now where Germans were at 1944. By suggesting that Muslims can also be democratized in the future if they follow the footsteps of post-War Germans, they located German Muslims in 
Germany's past, but with a developmental path towards a secure future; what Kosseleck calls in Germany's "past future” (Kosseleck 2018: 102). Their model of relating to the German past is "path dependent" (Olick 1999: 382), meaning the way they want to include Muslims in the German national temporality by replicating not necessarily how German democratization happened, but rather how it is remembered.

An interesting twist in this narrative is the fact that a popular explanation about why National Socialism took place is that Germany itself was a late comer to European modernity and has to follow the footsteps of West Europeans. As first formulated in the book The Belated Nation by Helmut Plessner in 1959, it is argued that Germany missed the opportunity to build a strong bourgeoise in the $17^{\text {th }}$ century and hence could not establish a modern liberal democracy. Its desperate attempts to catch up with the West led it to take a special path, Sonderweg, which then led it to the Third Reich. Since then Anglo-American scholars (Eley and Blackbourn 1984) refuted this thesis and showed that Germany did not majorly differ from other European countries and there is no one path towards modernization, however the theory is still popular. Hence, even in their being belated, Muslims are implicitly likened to Germans, and depicted as carrying the hope of democratizing themselves if they walk through the footsteps of Germans, who found the right path after learning from their mistakes. When Muslims are included in this evolutionary temporality, via taking up the location of late comer in relation to Germans, Germans inevitably move up to an advanced stage in the linear path. Below I discuss three major and interconnected yet independent aspects of postwar German history as they relate to one another layer upon layer, each straining the other's flow and impeding interpretation in the present as a condition of "simultaneity of the unsimultaneous" (Kosseleck 2000) and hence forming a "memory genre" to be followed (Olick 1999). 


\section{Nazis as redeemable naughty boys}

After the defeat of the Germans in 1945, not all Allies shared the opinion that Germans could be easily rehabilitated. The Americans were influential in convincing others that Germans could be de-Nazified and redemocratized if their culture-especially German family relations — could be transformed. The American Department of War worked closely with psychologists, anthropologists, and sociologists in crafting a narrative that would explain Nazism as a psychocultural problem specific to German culture, especially their child-raising methods. This approach developed in the US with the help of German émigré scholars mainly ignored social and economic explanations behind the rise of National Socialism and reduced it to a matter of socio-cultural socialization. Ashis Nandy (2009) has demonstrated how both Orientalist and colonial discourses imagine others as children that need to be governed and controlled. What was unique in the social science produced around the time of the Allied occupation of Germany was the depiction of German difference as that of a gifted child, one that can easily be convinced via American-style child raising to change his- here the emphasis was specifically on young men—bad behavior and grow himself up into a responsible adult (Fay, 2008). A 1943 US government report with the title How to Treat Germans advised careful handling: "One of the leading nations within the framework of our civilization, Germany, has to be handled as a gifted but dangerous boy who must be watched and controlled by strict though well-meaning masters" (quoted in Fay, 2008: 1). American occupiers and the social scientists who worked with them saw in Germany the potential for a bright future, lead the belated/infantile nation out of its Sonderweg and towards the right path of modernization and adulthood. 

immigrant integration. Memory Studies. ISSN 1750-6980 (In Press)

Hence, in teaching democracy to Germans, Western occupiers approached them as children and in turn Germans themselves approached Nazis as naughty boys. In other words, Nazi criminality came to be seen as a case of juvenile delinquency. In his psychological bestseller, Childhood and Society, the American German Jewish émigré Eric Erikson (1963) discusses German identity through "the legend" of Hitler's childhood. According to him, Hitler was "an adolescent who never gave in," "a glorified older brother, who took over the prerogatives of the fathers without overidentifying with them" (Erikson, 1963: 337). According to Erikson, because Hitler and Nazism had hypnotized Germans with black-andwhite thinking, the youth were unable to go through the healthy stages of puberty. Instead they became stuck in a protracted stage of adolescence and endless rebellion. Hitler's adolescent rebellion was popular among Germans, he argued, because pre-Nazi German manhood had been wedged between harsh and authoritarian treatment toward the wife and children at home and submissive acquiescence to other men at work. It is telling that the most important findings published by those American social scientists who worked closely with the occupying American appeared in the American Journal of Orthopsychiatry. Mosby's Medical Dictionary (Harris, Nagy, and Vardaxis, 2014) defines this subdiscipline as "the branch of psychiatry that specializes in correcting incipient and borderline mental and behavioral disorders, especially in children, and in developing preventive techniques to promote mental health and emotional growth and development."

In evaluation of the problematic aspects of the German family, fathers were seen as the main suspects who led their sons to turn towards authoritarianism. This model was especially potent for re-democratization because it put the guilt on the older generation and depicted younger Germans as innocent and changeable. Accounts by German historians suggests that a 
psycho-culture-centered understanding of democracy was embraced by many Germans, especially the Christian circles, as early as the late 1940s. By the 1950s, notions such as "democratic family" and "democratic fatherhood" as a way out of Nazi mind set enjoyed wide circulation (Van Rahden, 2011). It was suggested at the time that "only children who were raised to be mature members within [a democratic family] could later be expected to participate responsibly in social and political life" (Van Rahden, 2011: 68). As from 1955, and the end of Germany's occupation, a strong focus on fatherhood remained even as fatherhood's content changed. Numerous publications and films encouraged fathers in their paternal and civic responsibilities, seen as necessary "for the future of the West German family and the nation" (Van Rahden, 2011: 120).

\section{Democratization through youth rebellion}

With the student movement of 1968 , a second German attempt to come to terms with its Nazi past was launched. This time, the focus was on Germans shedding Nazi culture not as children who should be properly raised by good fathers, but as youth (students) who must rebel against their Nazi fathers. 1968 in Germany has been characterized as an "anachronistic rebellion" and "a desperate attempt to correct history retroactively" (Schmidt, 2010: 270). The German student rebellion against authority specifically aimed at destroying retrospectively the culture and ideology that had led to the Holocaust. In Hans Kundnani's words a good portion of the ' 68 generation "spen[t] their entire lives attempting to escape their fathers' influence and to become the opposite of their fathers - and perhaps in doing so to atone for their father's sins.” (Kundnani, 2009: 11) Herbert Marcuse, a German Jewish émigré to the US considered "the father of the new left," specifically instructed German youth to rebel against their fathers and to not take on their guilt (Marcuse, 1971: 9). A number of '68ers 
subsequently published novels and memoirs about their struggles with their fathers, a genre called Vaterliteratur (Schneider and Daniel, 1984).

If one major theme of the ' 68 movement was to dissociate with their fathers (Kundnani 2009, Schmidt 2010), a second was the need to rebel against Nazi ideology by taking a standing against sexual oppression and strict paternal authority, which '68ers saw as defining features of Nazism. This branch, inspired by the radical Jewish Austrian psychoanalyst Wilhelm Reich who had died a decade before the ' 68 movement and led by the activist Dieter Kunzelmann, believed that to transform German society and break from of the leftovers of fascism, bourgeois sexual conventions and family arrangements needed to be demolished (Kundnani, 2009: 52). Originally published in 1933, Reich argued in The Mass Psychology of Fascism (1970) that the masses had turned to authoritarianism as a result of sexual oppression. "The moral inhibition of the child's natural sexuality [...] makes the child afraid, shy, fearful of authority, obedient, 'good,' and 'docile' in the authoritarian sense of the words. It has a crippling effect on man's rebellious forces.... Thus, the family is the authoritarian state in miniature..." (Reich, 1970: 30). Kunzelmann's Kommune 1 and other communes that followed held daily collective psychoanalysis sessions, rejected monogamy, experimented with drugs and sexuality in order to break with moral inhibitions and their authoritarian tendencies. They believed that if young people can liberate themselves sexually, they might then be able to resist the remnants of fascism in Germany and resolve social and political injustices (Herzog 1998).

Dagmar Herzog (1998), German American historian of sexuality, argues that the sexually conservative attitudes that '68ers fought against so adamantly as the root of Nazi ideology was in fact not part of Nazi culture but rather a product of Christian ideology that 
came to dominate postwar German society in the 1950s. Members of the student movement experienced multiple sediments of history simultaneously, imposing one atop another. They aimed to transform their present experience with a past they remembered anachronistically in the first place, imagining their parents as sexually oppressed and authoritatively controlled by their parents. Both the first and second waves of German democratization where characterized by a strong desire to undo the past coupled with a utopian belief in the potential of youth.

\section{Competing visions of Muslim minority integration}

As a generation of German youth were challenging traditional understandings of family, sexuality, and child raising, millions of so-called guest workers from rural backgrounds in Italy, Spain, and Turkey were arriving. Often seen as unconnected to German attempts to come to terms with the Holocaust, the history of immigration in Germany is in fact deeply connected to it. Despite being commonly imagined as a merely postwar phenomenon, Turks and Turkish Jews were already present in Germany during the Third Reich and were part of Holocaust history as collaborators, by-standers, and victims (Baer, 2013). In the following decades a number of immigrant-background artists (Konuk, 2007), activists (Yurdakul and Bodemann, 2006), and lay citizens (Rothberg and Yıldı, 2011; Partridge, 2010) have taken part in the complex path of coming to terms with the German past, however these engagements have remained at the margins of German national narratives and consciousness.

Muslim-background public intellectuals started to play a significant role in mainstream German memory culture only in the 2000s through their likening of Islam/Muslims to Nazi ideology or to the pre-war German culture that led to Nazism especially in their approach to faulty child-raising methods and sexual oppression. Islam critics built on the theories of authoritarian national character studies, originally developed to explain Nazism, to argue that 
authoritarian fathering practices lead to violent, paranoid, and anti-Semitic adolescents fit only for authoritarian ideologies. They describe in detail a timeless Muslim family and overtly or covertly liken it to the Nazi family that the American occupiers and later the 1968 movement set out to demolish. ${ }^{\text {ii }}$

In his bestseller book Generation Allah, Ahmad Mansour (2014) combines his personal experiences growing up in a Palestinian village in Israel and his encounters with Muslims as a social worker in Germany over the past ten years with pseudoscientific statements about how a homogenized Muslim psycho-culture works across time and place. The Muslim family he depicts is a cruel one that aims to break the will of their children, wields verbal and emotional violence, and gives no space for independence. Mansour itemizes the damage children suffer within this collectively psychiatrized Muslim family and warns his readers how such bad child-raising practices can lead to dangerous results for Muslims and for German society alike. Because, according to him, this is a general psychocultural problem for all Muslims and the threat Germany faces comes not from a few hundred fanatic Islamists, but from the entire generation of young Muslims-Generation Allah—who are all under threat of Islamic radicalization (Mansour, 2014: 32). By calling Muslims Generation Allah and focusing mainly on youth, Mansour depicts all Muslims as troubled youth, who need to be ruled and governed but who can also be seen as innocent and hence transformed through the right methods. The dynamics of the Muslim family he depicts, and the end results he warns against are strikingly similar to authoritarian family models developed by post-War American and émigré scholars such as Eric Erikson and then intellectuals of the 1968 movement that explain and cure the German authoritarian family structure. 

immigrant integration. Memory Studies. ISSN 1750-6980 (In Press)

Both Mansour's book and the social project he popularized in Germany for sexual equality and against the pressure of honor Heroes (Bundesamt, 2007) feature the concept of "honor culture," used interchangeably with Islam. According to Mansour, sexual control of women prevents Muslims from adopting the democratic culture of Germany. He builds a model of a catastrophic Muslim child development that oppresses not only sexual drives but also the development of a healthy and mature personality. According to Mansour, sexual oppression is the root of honor culture and the source of radicalization among Muslim youth:

My observations suggest that the suppression of sexuality is one of the key factors of people's radicalization. (...) In a shame culture, where modesty is a positive value, genders are segregated, and sex is taboo, neither men or women can develop their individuality. This produces suffering, anger, anxiety, a feeling of being torn, depression, and violence. Especially for young men, it creates a considerable and often dangerous potential for violence. (Mansour, 2014: 129).

According to Mansour, and post-war scholars of national character studies, in patriarchal families with authoritarian fathers, boys develop a strict, zealous, and intolerant superego, have a black and white perception of right and wrong, respect submission to authority, have a negative view of people, and are preoccupied with violence and sex (Adorno et all, ,1950; Mansour, 2014) Strictly patriarchal families prevent children from experiencing healthy adolescence which they should be able to grow out of. Since they cannot grow out of it, they can never become mature adults fit for democracy. According to Mansour this dynamic becomes especially worse for Muslims because they have an equally strict patriarchal image of God, which makes the authority of the father even stronger (Mansour 
2014: 106). As Muslims get stuck in adolescence, they turn towards Islamic radicalization which places them in rigid authority relations with clear rules.

Mansour also posits an alternative Muslim father model experienced especially in Western Europe: the dysfunctional father. According to him this is equally if not more dangerous for the development of children.

Here, we have a disempowered father who is to some extent a phantom. Whether it is because he has lost his job, his self-esteem, his ability to be a role model, or because he shows weakness for other reasons. Let's look at a father who speaks broken German, while his son and daughter speak the language fluently. The more the father tries to regain his authority, the more he loses it. Often such children look for other authority figures, role models, and idols which can act as a substitute for the idealized father fantasy. (Mansour, 2014:106-17).

This dysfunctional dynamic is again, according to Mansour, especially problematic for Muslim children because for them the search for a replacement father figure leads them to Allah and his representatives. "Whoever has experienced an unhealthy relationship with their father is receptive to a version of Allah that is punishing, revengeful, and angry." Children who grow up in such families, he contends, will inevitably find Salafism, a puritanical approach to Islam which Mansour professes expertise on. "The Salafistic God-phantom correlates with a longing resulting from dysfunctional and often traumatic experience in early childhood. Its promise of paradise and rigidity is enormously complementary to the damaged psyche" (Mansour, 2014: 108). In other words, Mansour argues if the Muslim father is authoritarian his children will become radicals because they are comfortable only in 

immigrant integration. Memory Studies. ISSN 1750-6980 (In Press)

frameworks of authority and if he is an absent father his sons will again be radicals by looking for authoritarian substitutes. Like pre-war German fathers simultaneous "aloofness and harshness" at the same time (Erikson 1963: 332) led to the development of their children turning Nazism, Mansour argues the Muslim fathers' simultaneous strictness and absence lead their sons towards Islamic radicalization. In his model, Muslim children live completely cut off from mainstream German society and whatever bad happens to them is exclusively the result of the wrong Islamic family values.

Among the youth programs Mansour runs or advises is an Islamic deradicalization program called Hayat (Life in Arabic and Turkey) funded by the German Federal Office for Immigration and Refugee Affairs. ${ }^{\text {iii }}$ Hayat is housed at Society for Democratic Culture which is known for the award-winning neo-Nazi radicalization program founded by an ex-police detective and an ex-neo-Nazi leader in 2000. In 2011 the organization decided to transfer its know-how on working with neo-Nazis to working on radicalized Muslims. On their web page the project is defined in following words: "Hayat is the first German counseling program for persons involved in radical Salafist groups or on the path of a violent Jihadist radicalization, including those travelling to Syria and other combat zones." iv Even though the brochures produced by Hayat recognizes that only very few of Salafis are violent, in line with Mansour's model it approaches all Salafis as threats to democracy: "the "moderate" representatives of Salafism in Germany stand for positions and perspectives, which can be regarded as a threat to democracy - for example, when they defame and demarcate different thinking and living. Against this background, Salafi ideologies are not only a topic of security policy, but also a field for pedagogy and political education.” (ibid). Hayat equalizes neoNazi radicalism with Salafism and uses the same approach to deal with both groups. One of 

immigrant integration. Memory Studies. ISSN 1750-6980 (In Press)

the few entries in their web page is a manual on how to raise children - specifically prescholars - democratically. The document recommended that that families include everyone in the decision-making process, family members make arguments to convince others, and in the end, members vote by raising hands. The idea is very similar to one developed in the 1950s is that children who are raised with democratic methods will not turn towards radicalism.

Necla Kelek, a Turkish-background sociologist and the most vocal Islam critic in Germany, is in complete agreement with Mansour that the lack of good father models is at the root of the problem with male Muslim adolescents in Germany and elsewhere. In a debate she participated where she argued against building new mosques in Germany, Kelek emphasized how mosques are harmful for society because Muslim fathers spend too much time there. Mosques, she argues make Muslim fathers both too strict and absent at the same time.

Neither the high number of young men who leave school without graduating — 60 percent of them come from Muslim families—or the Turkish boys who hang round on the streets are a coincidence. They have no fathers as role models - because they are sitting at the mosques. And the more fathers sit at the mosques, the more rigid they become. They obey God, come home and force others to obey them. The fathers are not friends to their sons, they do not take care of them and they have no loving relationship with their wives. (Kelek et al., 2007).

In her 2006 book, The Lost Sons: A Plea for the Liberation of Turkish Men, in which she interviews Muslim men in German prisons, Kelek emphasizes her own struggle with her father. Without telling us the content of their conflict, she claims that when she was seventeen 
years old she had an argument with her father and that he chased her around the house with an ax. By her account, once her father understood that he no longer had authority over the family, he left the house, upon which she and her brothers celebrated his departure. Kelek attributes her success in life as an independent person to having been able to rebel against her father and having won the fight. In this way, she presents herself as a model rebel other Muslims should imitate if they want to be independent and successful individuals.

Seyran Ateş, a Turkish- and Kurdish-background lawyer and feminist activist who recently became a liberal imam, also argues in her book Islam Needs a Sexual Revolution (2011) that this Islamic emphasis on obedience to parents is what keeps Muslims from becoming mature adults and citizens suitable for a democratic regime. "The rebellion against authority, whether it be the state or family members, especially father and mother, has no political character in the Islamic world. Thus, submission and obedience remain with a great many Muslims for a lifetime” (Ateş, 2011: 92). According to Ateş, the sexual revolution helped people in the world, above all Germans, to get rid of their sexual oppression which was the cause of national socialism in the first place. According to her, having learned from Wilhelm Reich, the 68-movement fought against sexual oppression. Because they knew that: "An inhabited sexuality leads to aggression and frustration and encourages empathy for dictatorial systems" (Ateş, 2011: 87). For her, today, the Muslim world is just like the presexually liberated and pre-de-nazified Germany: "When I look at the Muslim world, I see exactly the Western youth of the 1960s. I myself grew up with the ideas of honoring older people, paying them respect (even if they make mistakes) and obeying them, because they did everything better and made all the decisions. In the Muslim world children understand nothing and have no rights. Whoever does not follow rules and orders, who is open-minded or stands up, get a hitting. My childhood is only some time back, but the majority of Muslim children who are growing up today are still being raised 
Ozyurek, Esra (2019) Muslim minorities as Germany's past future: Islam critics, holocaust memory, and immigrant integration. Memory Studies. ISSN 1750-6980 (In Press)

the same way." (Ateş, 2011: 92). As a European Muslim, Ateş believes it her duty to encourage rebellion first among European Muslims and then among the Muslim population at large so that they can be democratized.

While these writings share in the common European trope that views both colonial subjects and minorities as troubled children who need to be monitored and disciplined (Nandy, 2009) and in colonial distinctions between colonizers and the colonized secured through sexual control and middle-class notions of respectability (Stoler, 1989), they are nevertheless distinct. The way in which the Muslim problem is turned into the figure of the unruly male adolescent whose sexuality and violence is out of control is unique in its connections to discourses about the Nazis conceptualized by postwar Americans and Germans. This trend of likening Muslims to Nazis shares parallels with the discourse that likens pre-WWII German culture to culture in the German Democratic Republic (Borneman, 1993; Glaeser, 2000). Anthropologist Nitzan Shoshan (2017) has argued that "the contrast with East Germany allowed the West to corroborate and reaffirm its liberal democratic credentials and hence to fortify its claim to a radical difference with the Third Reich. After 1989, however, the East has continued to serve the same purpose, casting Germany's liberal democratic society as mature enough to crusade for what it once had to be taught" (Shoshan, 2017: 41). Muslim background Islam critics attempt to liken the Muslim problem to that of the East German problem and by doing so they appeal to liberal and also right-wing groups by indicating that Muslims are capable for following first West and then East Germans and finally achieve democratization.

\section{Muslims to engage Germany's past, Germans to get over it}


Collapsing the Nazi past with that of the Muslim present allows Islam critics like Mansour and Ateş to depict Muslims as redeemable and worthy of expensive social rehabilitation projects. Given the correct methods-which Mansour and Ateş claim to have mastered-Muslims can be Germany's past future and march through the same stages toward democratization that Germans have. In his writings, Mansour suggests that if Nazis could be rehabilitated, then so can Muslims. After a long passage on problematic Muslim child-raising techniques, Mansour writes, "The revolts of 1968 prove that this dynamic may be lifted.... The '68 generation broke their identification with their fathers and condemned their acts.... What patriarchal societies need more than anything else is just such a rebellion against the authority of their fathers and normal family violence" (Mansour, 2014: 105).

Yet with such a project comes the price of shifting the responsibility of coming to terms with the Holocaust onto the shoulders of the Muslim minority, and by doing so lightening the burden on German shoulders. It is noteworthy that Islam critics took on the position of likening Muslim culture with that of the German culture during Nazism after the building of the massive Memorial for the Murdered Jews of Europe in 2004, which number of sceptics saw as reflective of a desire to have "a place where Germans would come dutifully to unshoulder their memorial burden, so that they could move freely and unencumbered into the twenty first century" (Young 2002: 70). Poignantly, the very same Islam critics who encourage Muslims to follow in the footsteps of Germans who rebelled against their parents, their authoritarian culture, and Nazi crimes also encourage native-background Germans to stop taking the heritage of the Holocaust too seriously and move forward. Germans should in short get over the Holocaust. Islam critics warn the majority population that their guilt in relation to the Holocaust makes them "falsely" tolerant of Muslims, who actually are the real 
Ozyurek, Esra (2019) Muslim minorities as Germany's past future: Islam critics, holocaust memory, and immigrant integration. Memory Studies. ISSN 1750-6980 (In Press)

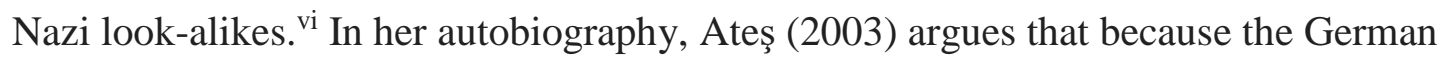
government has since the end of WWII been unnecessarily too careful not to appear racist, a problematic atmosphere developed wherein September 11 attackers could flourish in Germany. “This false dream of tolerance and Germany's fear of being called racist are helping fundamentalists" (quoted in Ewing, 2008: 162). In The Foreign Bride, Kelek (2005) makes a similar argument:

"There is a panicked fear of discriminating against Islamists because of their religion or background; one prefers to condone their infringement of fundamental rights instead. This, however, stems from the specific identity problem of Germans.... Germans have deeply engaged with their Nazi past and the crimes against others. This surely has contributed to the civil and democratic character of this republic. But at times the special feelings of guilt toward Jews, Sinti, Roma, homosexuals and others block the clear view on today's realities of oppression and exclusion" (quoted in Y1ldı, 2011: 89).

Yasemin Y1ldız (2011) argues that Islam critics such as Necla Kelek point to a move away from left-liberal European stances on victim-centered Holocaust memory culture such as that represented by Jürgen Habermas. I suggest that Islam critics in fact take yet another and more consequential step — they insist that Muslims should not be likened to Jewish victims under the guise of fake tolerance but should instead be likened to Nazi perpetrators. Simultaneously they promote a shift in focus from Muslim women as victims of oppression to Muslim men as oppression's perpetrators. Not Kelek or Abdel-Samed, but Ateş and Mansour see in that likening a chance to include Muslims in the German national timespace. In Muslims these Islam critics see the same potential that American occupiers saw in German 
Ozyurek, Esra (2019) Muslim minorities as Germany's past future: Islam critics, holocaust memory, and immigrant integration. Memory Studies. ISSN 1750-6980 (In Press)

youth in the late 1940s, that German students saw in themselves in 1968. Furthermore, by making pointing out fascistic tendencies in their own communities and shepherding them towards democracy, they themselves model on walking on the footsteps of post-War German intellectuals. The other corollary of such an historical equation between Muslims and postWar Germans is to argue that Germans have already reached their destination and became the mature adults the American occupiers of WWII hoped for. Having proved themselves, Islam critics suggest, Germans can now stand in the shoes of the occupying American forces and can focus on rehabilitating Muslims by being good role models for them.

\section{Conclusion}

In 1979, Reinhardt Koselleck wrote the following prescient words:

"The events of 1933 [when the Nazis came to power] have occurred once and for all, but the experiences which are based upon them can change over time. Experiences overlap and mutually impregnate one another. In addition, new hopes or disappointments, or new expectations enter them with retrospective effect. Thus, experiences alter themselves as well, despite, once having occurred, remaining the same. This is the temporal structure of experience and without retrospective expectation it cannot be accumulated" (Koselleck, 2004: 262).

Muslim-background Islam critics establish a linear German national temporality and suggest that Muslims can also enter it from point zero, the same place where defeated Germans started in 1945. After depicting a timeless Muslim family that suffers from the most troubling aspects of the purported German family that led to Nazism, critics reason that if 

immigrant integration. Memory Studies. ISSN 1750-6980 (In Press)

Muslims are treated rightly as children who have been incorrectly parented and as adolescents who have been unable to free themselves from social and sexual authority, they can also be democratized. In so doing, Islam critics contend that the German experience of having learned from the mistakes of 1933 can be repeated and will be liberating. Islam critics themselves replicate many of the opinions produced by post-War German intellectuals about German society and promote the idea that together with Germany they can lead the Muslim communities out of authoritarianism and towards democratization.

In making this historiographic claim, their goal is clear: at the expense of equating racialized Muslim minorities with defeated Germans, they seek to include Muslim minorities into the German fold by placing them on the timeline of German national temporality-even if they place them at the start, behind the present at point zero. With this rhetorical move, Muslim public intellectuals send the message that the majority German populace has reached its destination in their journey towards democratization and should no longer feel guilty for the sins of their Nazi fathers, most especially in relation to Muslim minority groups. This historical rubric about learning from the Holocaust, envisioned as a linear evolutionary historicity with Muslims at the starting point and Germans having reached the destination, is crucial to the way center-right Germans relate to the past, the present, and the future in Germany today.

The suggestion that Muslims in Germany and elsewhere should repeat what postwar Germans did in order to liberate themselves from their authoritarian culture creates a puzzling reordering of unconnected temporalities. One important aspect of equating contemporary Muslims with defeated fascists of a generation or two ago is to go against a more essentialist and racializing view that Muslims are completely different people who live in their own 

immigrant integration. Memory Studies. ISSN 1750-6980 (In Press)

national time and hence can never connect with Germans. Rather, Islam critics more to the left end of the spectrum suggest, Muslims are just a few decades behind Germans and can catch up when approached with the right policies. In other words, this discourse assigns contemporary Muslims to Germany’s “past future” (Koselleck 2018: 102), a future that was once aspired for defeated Nazis by their Allied victors and later by the Germans themselves. This emphasis on hope for a better future makes itself clear in the way that the American occupiers of 1945 often viewed Germans as naughty boys, mainstream German society saw '68ers as rebellious youth, and Muslim background critics of Islam regard Muslim minorities as adolescents. Islam critics under study here declare Germans to have realized their potential and as mature adults who live in "future present" (Koselleck, 2018: 102), a way of being that will last into the future. In so doing however, however, they erase Muslim minorities from the "present present" (Koselleck, 2018: 102) that they have been cohabiting together with the German majority.

The idea that the process of German democratization is a formula that different nationalities can repeat, including Muslim minorities, is enabled by a historicity prevalent since the end of WWII whereby different sediments of time flow simultaneously and in tension with each other. In postwar Germany, a conservative trajectory that prioritized family values, a left-liberal trajectory that promoted sexual freedom, a process of coming to terms with the crimes of the Third Reich, and an immigration history that made Germany plural but also resurfaced racializing tendencies all flow as historical sediments in relation to one another, alongside many other social processes: an aging population, economic success, refugee crisis that brought the deep challenges of European Union to surface, and ever shifting global political alliances. The defeat of the Third Reich and the potential its occupiers 
Ozyurek, Esra (2019) Muslim minorities as Germany's past future: Islam critics, holocaust memory, and immigrant integration. Memory Studies. ISSN 1750-6980 (In Press)

saw in Germans despite the horrors they caused, and how democratization is remembered today serves as the trigger generating trajectories into the future which all flow coevally but at their own speed.

\section{References}

Abdel-Samad H (2016) Islamic Fascism. New York: Prometheus Books.

Adorno TW, Frenkel-Brunswik E, Levinson DJ, Sanford N (1950) The Authoritarian

Personality. New York: Harper and Row.

Assmann A (2014) Transnational Memories. European Review. 22(4): 546-556.

Ateş S (2003) Große Reise ins Feuer: Die Geschichte einer deutschen Türkin. Berlin:

Rowohlt Verlag.

Ateş S (2011) Der Islam braucht eine sexuelle Revolution: Eine Streitschrift. Berlin: Ullstein Buchverlage.

Baer MD (2013) Turk and Jew in Berlin: The first Turkish migration to Germany and the Shoah. Comparative Studies in Society and History 55 (02): 330-355.

Borneman J (1993) Uniting the German nation: Law, narrative, and historicity. American Ethnologist 20(2): 288-311.

Brickner RM (1945) Germany after the War-Round Table 1945. American Journal of Orthopsychiatry 15 (1945): 381-441.

Bundesamt für Migration und Flüchtlinge (2007) Heroes - Gegen die Unterdrückung im Namen der Ehre und für Gleichberechtigung. Available at: http://www.bamf.de/DE/DasBAMF/Clearingstelle/Projekte/projekte-detailansichtnode.html?projectDataId=761\&sortString=-audience (accessed 17 July 2018). 
Ozyurek, Esra (2019) Muslim minorities as Germany's past future: Islam critics, holocaust memory, and immigrant integration. Memory Studies. ISSN 1750-6980 (In Press)

Chakrabarty D (2000) Provincializing Europe: Postcolonial Thought and Historical Difference. Princeton: Princeton University Press.

Crolly, H. (2007) „Der Islam ist vergleichbar mit dem Faschismus" Die Welt. https://www.welt.de/politik/article1093836/Der-Islam-ist-vergleichbar-mit-demFaschismus.html

Doughan, Sultan. 2013. "Deviation: The Present Orders.” Cultural Anthropology website.

El-Tayeb F (2016) Undeutsch: Die Konstruktion des Anderen in der postmigrantischen Gesellschaft. Bielefeld: Transcript Verlag.

Erikson E (1963) Youth: Change and Challenge. New York: Basic Books.

Ewing K (2008) Stolen Honor: Stigmatizing Muslim Men in Berlin. Stanford: Stanford University Press.

Fabian J (1983) Time and the Other: How Anthropology Makes its Object. New York: Columbia University Press.

Fay J (2008) Theaters of Occupation: Hollywood and the Reeducation of Postwar Germany. Minneapolis: University of Minnesota Press.

Finger, E (2015) "Der Islam ist keine Religion des Friedens" Zeit Online. https://www.zeit.de/politik/ausland/2015-12/hamed-abdel-sama-islam-kritik-muslimefundamentalismus

Flanzbaum H. (1999) Americanization of the Holocaust. Baltimore: Johns Hopkins University Press.

Fox T (2001) Stated Memory: East Germany and the Holocaust. Rochester: Camden House. 
Ozyurek, Esra (2019) Muslim minorities as Germany's past future: Islam critics, holocaust memory, and immigrant integration. Memory Studies. ISSN 1750-6980 (In Press)

Frochtner B (2014) Rhetorics of Judge-Penitence: Claiming Moral Superiority through Admissions of Past Wrong Doing. Memory Studies 7(4): 409-24.

Glaeser A (2000) Divided in Unity: Identity, Germany, and the Berlin Police. Chicago: University of Chicago Press.

Grass, G (1980) Kopfgeburten oder Die Deutschen sterben aus. Darmstadt: Luchterhand. Harris P, Nagy S and Vardaxis N (2014) Mosby's Dictionary of Medicine, Nursing and Health Professions. Chatswood: Elsevier Health Sciences.

Herzog D (2007) Sex after Fascism: Memory and Morality in Twentieth Century Germany. Princeton: Princeton University Press.

Horkheimer M and Adorno TW (1947) Dialectic der Aufklärung: Philosophische Fragmente. Frankfurt: S. Fischer Verlag.

Huyssen A (2003) Present Pasts: Urban Palimpsests and the Politics of Memory. Stanford: Stanford University Press.

Kampe N (1987) Normalizing the Holocaust? The Recent Historians' Debate in the Federal Republic of Germany. Holocaust and Genocide Studies 2(1): 61-80.

Karyn B (2009) Disciplining the Holocaust. Albany: SUNY Press.

Kelek N (2005) Die fremde Braut: Ein Bericht aus dem Inneren des türkischen Lebens in Deutschland. Köln: Verlag Kiepenheuer \& Witsch.

Kelek N (2006) Die verlorenen Söhne: Plädoyer für die Befreiung des türkisch-muslimischen Mannes. Köln: Verlag Kiepenheuer \& Witsch.

Kelek N, Malzahn CC, and Reimann AA (2007) German Integration Summit: "We Really Have Nothing to Celebrate.” Spiegel Online International, 07 December, 2007. 
Ozyurek, Esra (2019) Muslim minorities as Germany's past future: Islam critics, holocaust memory, and immigrant integration. Memory Studies. ISSN 1750-6980 (In Press)

Klaieber, S. (2018). Islam-Debatte: Soziologin Kelek wirft Politikern "Verharmlosung von Religion" vor. Huffpost. https://www.huffingtonpost.de/entry/islam-debatte-soziologinkelek-wirft-politikern-verharmlosung-von-religion-vor_de_5aad9e9be4b0c33361b0f6e5

Konuk K (2007) Taking on German and Turkish History: Emine Sevgi Özdamar's Seltsame Sterne. Gegenwartsliteratur: German Studies Yearbook 6: 232-256.

Koselleck R (2000) Zeitschichten: Studien zur Historik. Frankfurt am Main: Suhrkamp.

Koselleck R (2004) Futures Past: On the Semantics of Historical Time. New York: Columbia University Press.

Koselleck R (2018) Sediments of Time: On Possible Histories. Stanford: Stanford University Press.

Kundnani H (2009) Utopia Or Auschwitz?: Germany's 1968 Generation and the Holocaust. New York: Columbia University Press.

Levy D and Sznaider N (2006) The Holocaust and Memory in the Global Age. Philadelphia: Temple University Press.

Mack MA (2017) Sexagon: Muslims, France, and the Sexualization of National Culture. New York: Modern Language Initiative.

Mandel R (2008) Cosmopolitan Anxieties: Turkish Challenges to Citizenship and Belonging in Germany. Durham: Duke University Press.

Mansour A (2014) Generation Allah: Warum wir im kampf gegen religioesen Extremismus umdenken muessen. Berlin: S. Fisher Verlag.

Marcuse H (1971) An Essay on Liberation. Boston: Beacon Press.

Markovits AS (2006) A New (or Perhaps Revived) "Uninhibitedness” toward Jews in Germany. Jewish Political Studies Review 18: 1-2. 
Ozyurek, Esra (2019) Muslim minorities as Germany's past future: Islam critics, holocaust memory, and immigrant integration. Memory Studies. ISSN 1750-6980 (In Press)

Mbembe A (2001) On the Postcolony. Berkeley: University of California Press.

Moses DA (2001) Coming to Terms with Genocidal Pasts in Comparative Perspective: Germany and Australia. Aboriginal History 25: 91-115.

Müller, Jan-Werner. (2000) Another Country: German Intellectuals, Unification, and National Identity. New Haven: Yale University Press.

Nandy A (2009) The Intimate Enemy: Loss and Recovery of Self under Colonialism. Delhi: Oxford University Press.

Niven B (2002) Germans as Victims: Remembering the Past in Contemporary Germany. New York: Palgrave.

Olick J (1998) What does it Mean to Normalize the Past? Official Memory in German Politics. Social Science History 22(4): 547-571.

Olick J (1999) Genre Memories and Memory Genres: A Dialogical Analysis of May 8, 1945 Commemorations in the Federal Republic of Germany. American Sociological Review. 64(3): 381-402.

Ozyurek E (2016) Export-Import Theory and Racialization of Antisemitism: Turkish and Arabonly Prevention Programs in Germany. Comparative Studies in Society and History 58 (1): 40-65.

Ozyurek E (2018) Rethinking Empathy: Emotions Triggered by the Holocaust among Muslim-minority in Germany. Anthropological Theory 18(4): 456-477.

Partridge D (2008) We were Dancing in the Club, not on the Berlin Wall: Black Bodies, Street Bureaucrats, and Exclusionary Incorporation into the New Europe. Cultural Anthropology. 23(4): 660-687. 
Ozyurek, Esra (2019) Muslim minorities as Germany's past future: Islam critics, holocaust memory, and immigrant integration. Memory Studies. ISSN 1750-6980 (In Press)

Partridge D (2010) Holocaust Mahnmal (Memorial): Monumental Memory amidst Contemporary Race. Comparative Studies in Society and History 52(4): 820-850.

Peristiany J (ed) (1966) Honour and Shame: The Values of Mediterranean Society. Chicago: University of Chicago Press.

Plessow O (2015) The Interplay of the European Commission, Researcher, and Educator Networks and Transnational Agencies in the Promotion of a Pan-European Holocaust Memory. Journal of Contemporary European Studies. 23(3): 378-390.

Ramadani Z (2017) Die Verschleierte Gefahr: Die mach der muslimischen Muetter und der toleranzwahn der Deutschen. Berlin: Europa Verlag.

Reich W (1970) The Mass Psychology of Fascism. New York: Farrar, Straus and Giroux. Rothberg M (2009) Multidirectional Memory: Remembering Holocaust at the Age of Decolonization. Stanford University Press.

Rothberg M and Y1ldız Y (2011) Memory Citizenship: Migrant Archives of Holocaust Remembrance in Contemporary Germany. Parallax 17(4): 32-48.

Schmidt C (2010) The Israel of the Spirit: The German Student Movement of the 1960s and its Attitude to the Holocaust. Dapim: Studies on the Holocaust. 24(1): 269-318.

Schneider M and Daniel JO (1984) Fathers and Sons, Retrospectively: The Damaged Relationship between Two Generations. New German Critique 31 (winter): 3-51 Schwarzer A (2002) Die Gotteskrieger und die falsche Toleranz. Kiepenheuer \& Witsch $\mathrm{GmbH}$

Shoshan N (2017) The Management of Hate: Nation, Affect, and the Governance of RightWing Extremism in Germany. Princeton: Princeton University Press. 
Ozyurek, Esra (2019) Muslim minorities as Germany's past future: Islam critics, holocaust memory, and immigrant integration. Memory Studies. ISSN 1750-6980 (In Press)

Sieg K (2010) Black Virgins: Sexuality and the Democratic Body in Europe. New German Critique 109: 147-185.

Stoler AL (1989) Rethinking Colonial Categories: European Communities and the Boundaries of Rule. Comparative Studies in Society and History, 31(1): 134-161.

Van Rahden T (2011) Clumsy Democrats: Moral Passions in the Federal Republic.German History 29(3): 485-504.

Von Bieberstein A (2016) "Not a German past to be reckoned with: negotiating migrant subjectivities between Vergangenheitsbewaeltigung and the nationalization of history" Journal of the Royal Anthropological Institute. 22(4): 902-919.

Welch S and Wittlinger R (2011) The Resilience of the Nation State: Cosmopolitanism, Holocaust Memory, and the Nation State. German Politics and Society. 29(3): 38-54.

Wilds K (2013) Cultural Memories of German Suffering during the Second World War: An Inability not to Mourn? In The Use and Abuse of Memory: Interpreting World War II in Contemporary European Politics, edited by Christian Karner and Bram Mertens, Transaction Books.

Wolfgram M (2011) “Getting the History Right”: East and West German Collective Memories of the Holocaust and War. Lewisburg: Bucknell University Press.

Y1ldz Y (2011) Governing European Subjects: Tolerance and Guilt in the Discourse of “Muslim Women.” Cultural Critique 77(1): 70-101.

Young, JE (2002) Germany's Holocaust Problem -- and Mine. Public Historian. 24(4): 65-80. Yurdakul G and Bodemann M (2006) “We Don't Want to be the Jews of Tomorrow:” Jews and Turks in Germany after 9/11. German Politics and Society 24(2): 44-67. 


\section{Endnotes}

${ }^{\text {ii }}$ In a brief discussion of her fieldnotes Sultan Doughan (2013) also suggests that Kosseleck is helpful to understand the tensions around Muslim participation in the German Holocaust memory culture.

ii A newer, but not yet popular discourse in Germany accuses Muslim women and specifically mothers for being the ones responsible for sexism and violence in Muslim communities (Ramadani, 2017). This discourse is already popular in France (Mack, 2017).

${ }^{\text {iii }}$ For the website see https://hayat-deutschland.de/english/ (accessed 27 March 2019)

${ }^{\text {iv }}$ For the website see https://www.exit-deutschland.de/english/ (accessed 27 March 2019)

${ }^{\mathrm{v}}$ Ateş had originally wanted to call the book I Fuck Whomever I Want, the alleged last words of Hatun Sürücü killed in Berlin at a bus stop by her brother in 2005 after divorcing her husband who was her cousin.

${ }^{\text {vi }}$ Feminist Alice Schwarzer (2002) began the conversation on "false tolerance" towards Muslims, likening them to fascists. Katrin Sieg (2010) argues that "the juxtaposition of an enlightened democratic European culture against an Islamo-fascist other outside and within its borders rests on reifying sexual liberty as an essential European trait and thus seeks to reconnect demos to ethnos in a regressive, exclusionary gesture” (182).

\section{Biography}


Ozyurek, Esra (2019) Muslim minorities as Germany's past future: Islam critics, holocaust memory, and immigrant integration. Memory Studies. ISSN 1750-6980 (In Press)

Dr. Esra Özyürek (PhD, Anthropology, University of Michigan) is an Associate Professor and Chair for Contemporary Turkish Studies at the European Institute, London School of Economics. She is the author of Being German, Becoming Muslim: Race, Religion, and Conversion in the New Europe (Princeton University Press 2014) and Nostalgia for the Modern: State Secularism and Everyday Politics in Turkey (Duke University Press 2007). She also is the editor of Authoritarianism and Resistance in Turkey (with Gaye Özpınar and Emrah Altındiş) (Springer 2018 Springer) and Politics of Public Memory in Turkey (Syracuse University Press 2007). 